Prepared in cooperation with the Indiana Department of Transportation

\title{
Flood-Inundation Maps for the Flatrock River at Columbus, Indiana, 2012
}

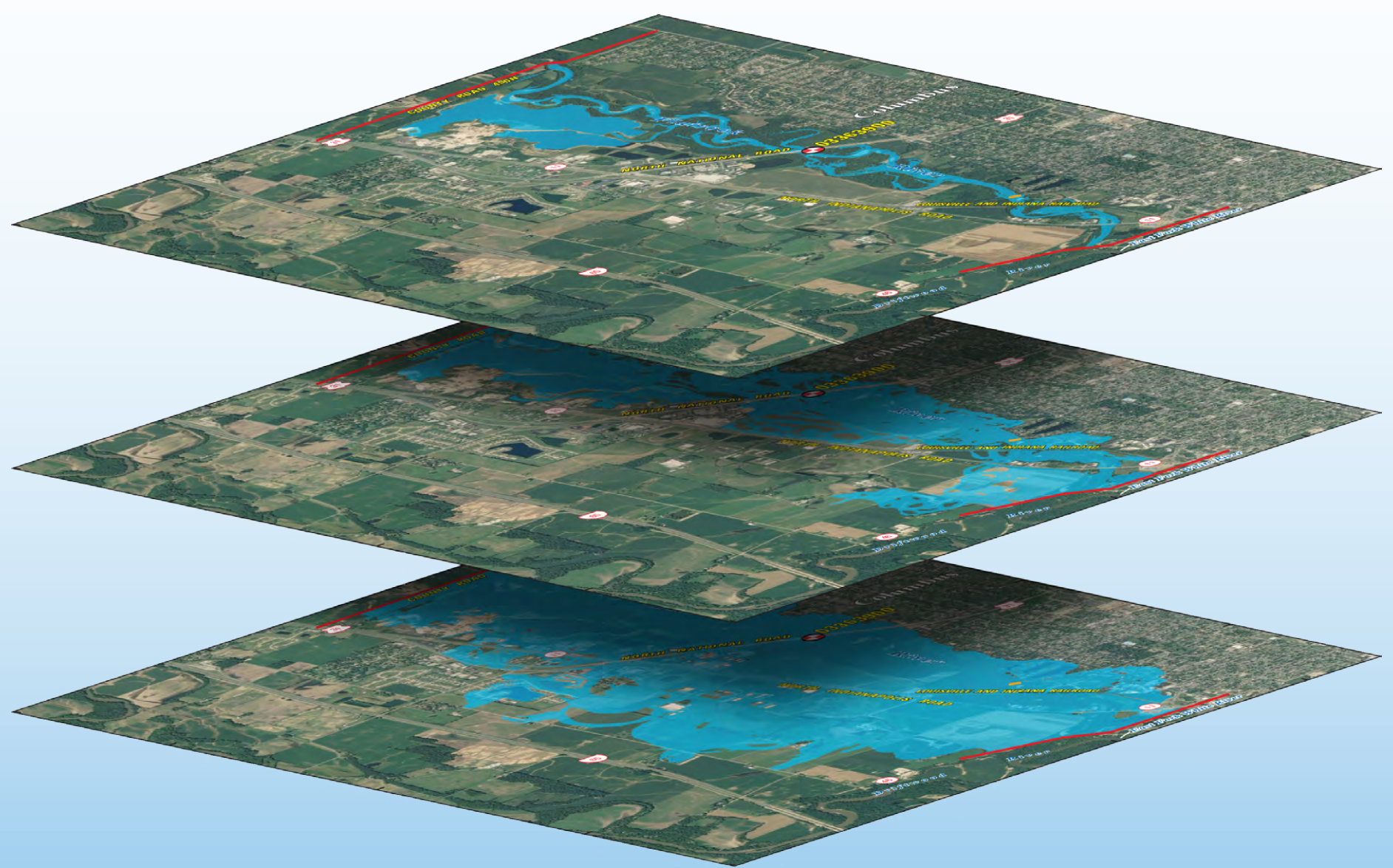

Pamphlet to accompany

Scientific Investigations Map 3241 
Cover. Illustration showing simulated floods corresponding to streamgage stages of 9, 13, and 20 feet for Flatrock River at Columbus, Indiana. 


\section{Flood-Inundation Maps for the Flatrock River at Columbus, Indiana, 2012}

By William F. Coon

Prepared in cooperation with the Indiana Department of Transportation

Pamphlet to accompany

Scientific Investigations Map 3241 


\section{U.S. Department of the Interior \\ KEN SALAZAR, Secretary}

\section{U.S. Geological Survey \\ Suzette M. Kimball, Acting Director}

U.S. Geological Survey, Reston, Virginia: 2013

For more information on the USGS - the Federal source for science about the Earth, its natural and living resources, natural hazards, and the environment, visit http://www.usgs.gov or call 1-888-ASK-USGS.

For an overview of USGS information products, including maps, imagery, and publications, visit http://www.usgs.gov/pubprod

To order this and other USGS information products, visit http://store.usgs.gov

Any use of trade, product, or firm names is for descriptive purposes only and does not imply endorsement by the U.S. Government.

Although this report is in the public domain, permission must be secured from the individual copyright owners to reproduce any copyrighted materials contained within this report.

Suggested citation:

Coon, W.F., 2013, Flood-inundation maps for the Flatrock River at Columbus, Indiana, 2012: U.S. Geological Survey Scientific Investigations Map 3241, 12 p., 12 sheets, available at http://pubs.usgs.gov/sim/3241 


\section{Contents}

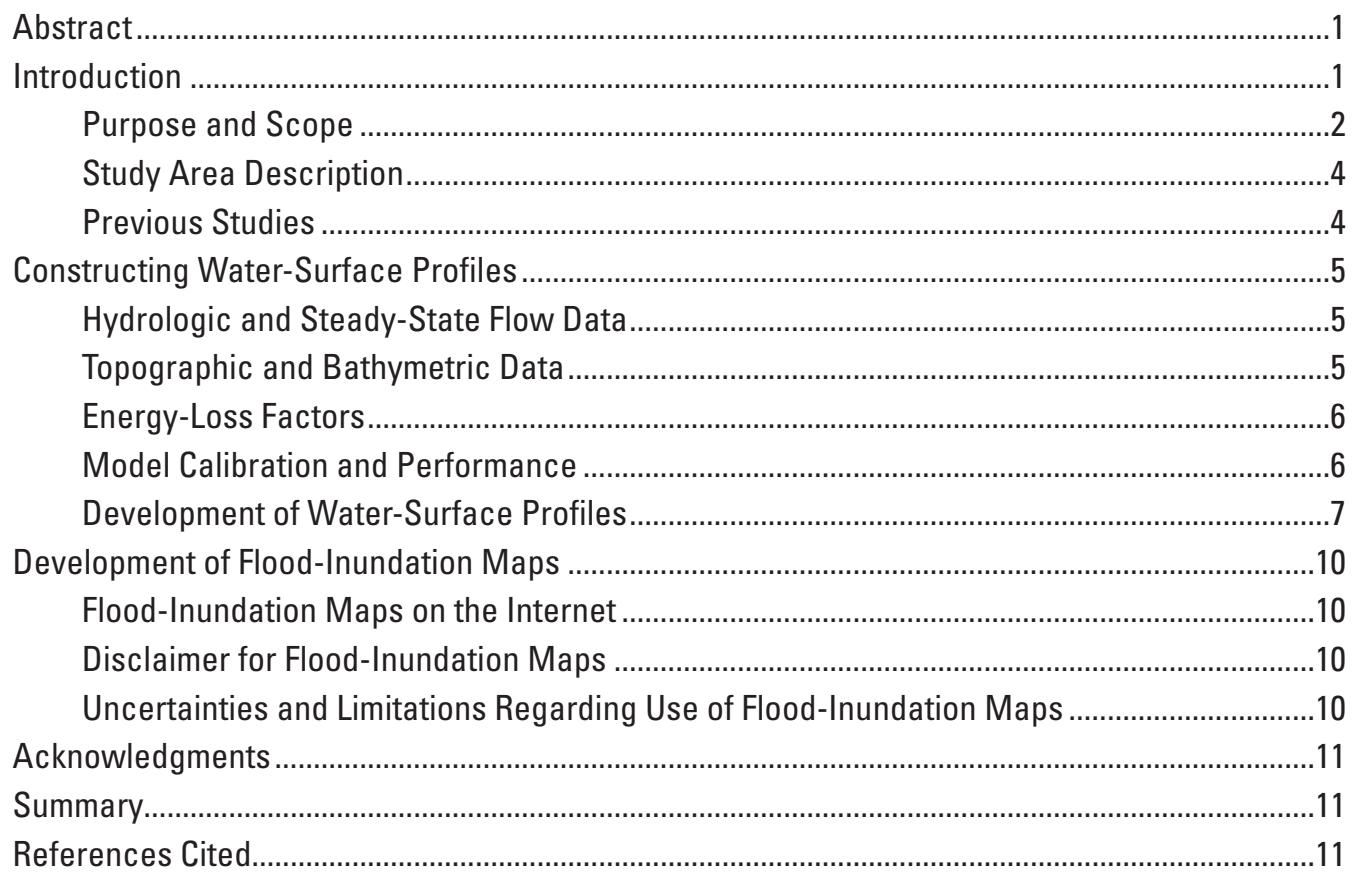




\section{Figures}

1. Location of study reach for the Flatrock River at Columbus, Indiana, and location of U.S. Geological Survey streamgage ...................................................................

2. Simulated water-surface profile at a streamgage stage of 20.00 feet and high-water marks surveyed following the flood of June 7, 2008, at a stage of 19.94 feet, Flatrock River at Columbus, Indiana

3. High water-surface profiles of the FEMA 1-percent annual exceedance probability flood and simulated floods corresponding to streamgage stages of 18 and 19 feet for Flatrock River at Columbus, Indiana.

4. Flood extents of the FEMA 1-percent annual exceedance probability flood and simulated floods corresponding to streamgage stages of 18 and 19 feet for Flatrock River at Columbus, Indiana

\section{Tables}

1. U.S. Geological Survey streamgage information for Flatrock River at Columbus, Indiana

2. Peak discharges for selected annual exceedance probabilities for Flatrock River at Columbus, Indiana (streamgage number 03363900)

3. Calibration of model to target water-surface elevations at U.S. Geological Survey streamgage on Flatrock River at Columbus, Indiana (station number 03363900) 


\section{Sheets}

[Separate documents available online with this report at the U.S. Geological Survey Publications Warehouse (http://pubs.usgs.gov/sim/3241/)]

1. Flood-inundation map for the Flatrock River at Columbus, Indiana, corresponding to a stage of 9.0 feet and an elevation of 618.74 feet (NAVD 88) at the U.S. Geological Survey streamgage number 03363900 on the Flatrock River

2. Flood-inundation map for the Flatrock River at Columbus, Indiana, corresponding to a stage of 10.0 feet and an elevation of 619.74 feet (NAVD 88) at the U.S. Geological Survey streamgage number 03363900 on the Flatrock River

3. Flood-inundation map for the Flatrock River at Columbus, Indiana, corresponding to a stage of 11.0 feet and an elevation of 620.74 feet (NAVD 88) at the U.S. Geological Survey streamgage number 03363900 on the Flatrock River

4. Flood-inundation map for the Flatrock River at Columbus, Indiana, corresponding to a stage of 12.0 feet and an elevation of 621.74 feet (NAVD 88) at the U.S. Geological Survey streamgage number 03363900 on the Flatrock River

5. Flood-inundation map for the Flatrock River at Columbus, Indiana, corresponding to a stage of 13.0 feet and an elevation of 622.74 feet (NAVD 88) at the U.S. Geological Survey streamgage number 03363900 on the Flatrock River

6. Flood-inundation map for the Flatrock River at Columbus, Indiana, corresponding to a stage of 14.0 feet and an elevation of 623.74 feet (NAVD 88) at the U.S. Geological Survey streamgage number 03363900 on the Flatrock River

7. Flood-inundation map for the Flatrock River at Columbus, Indiana, corresponding to a stage of 15.0 feet and an elevation of 624.74 feet (NAVD 88) at the U.S. Geological Survey streamgage number 03363900 on the Flatrock River

8. Flood-inundation map for the Flatrock River at Columbus, Indiana, corresponding to a stage of 16.0 feet and an elevation of 625.74 feet (NAVD 88) at the U.S. Geological Survey streamgage number 03363900 on the Flatrock River

9. Flood-inundation map for the Flatrock River at Columbus, Indiana, corresponding to a stage of 17.0 feet and an elevation of 626.74 feet (NAVD 88) at the U.S. Geological Survey streamgage number 03363900 on the Flatrock River

10. Flood-inundation map for the Flatrock River at Columbus, Indiana, corresponding to a stage of 18.0 feet and an elevation of 627.74 feet (NAVD 88) at the U.S. Geological Survey streamgage number 03363900 on the Flatrock River

11. Flood-inundation map for the Flatrock River at Columbus, Indiana, corresponding to a stage of 19.0 feet and an elevation of 628.74 feet (NAVD 88) at the U.S. Geological Survey streamgage number 03363900 on the Flatrock River

12. Flood-inundation map for the Flatrock River at Columbus, Indiana, corresponding to a stage of 20.0 feet and an elevation of 629.74 feet (NAVD 88) at the U.S. Geological Survey streamgage number 03363900 on the Flatrock River 


\section{Conversion Factors}

Inch/Pound to SI

\begin{tabular}{lcl}
\hline \multicolumn{1}{c}{ Multiply } & By & \multicolumn{1}{c}{ To obtain } \\
\hline & Length & \\
\hline foot $(\mathrm{ft})$ & 0.3048 & meter $(\mathrm{m})$ \\
mile $(\mathrm{mi})$ & 1.609 & kilometer $(\mathrm{km})$ \\
\hline & Area & \\
\hline square ${\mathrm{mile}\left(\mathrm{mi}^{2}\right)}$ & 2.590 & square kilometer $\left(\mathrm{km}^{2}\right)$ \\
\hline cubic foot per second $\left(\mathrm{ft}^{3} / \mathrm{s}\right)$ & Flow rate & \\
\hline
\end{tabular}

Vertical coordinate information is referenced to either (1) stage, the height above an arbitrary datum established at a streamgage, or (2) elevation, the height above the North American Vertical Datum of 1988 (NAVD 88).

Horizontal coordinate information is referenced to the North American Datum of 1983 (NAD 83). 


\title{
Flood-Inundation Maps for the Flatrock River at Columbus, Indiana, 2012
}

\author{
By William F. Coon
}

\section{Abstract}

Digital flood-inundation maps for a 5-mile reach of the Flatrock River on the western side of Columbus, Indiana, from County Road $400 \mathrm{~N}$ to the river mouth at the confluence with Driftwood River, were created by the U.S. Geological Survey (USGS) in cooperation with the Indiana Department of Transportation. The inundation maps, which can be accessed through the USGS Flood Inundation Mapping Science Web site at http://water.usgs.gov/osw/flood_inundation/ and the Federal Flood Inundation Mapper Web site at http://wim.usgs. gov/FIMI/FloodInundationMapper.html, depict estimates of the areal extent and depth of flooding corresponding to selected water levels (stages) at the USGS streamgage on the Flatrock River at Columbus (station number 03363900). Nearreal-time stages at this streamgage may be obtained on the Internet from the USGS National Water Information System at http://waterdata.usgs.gov/ or the National Weather Service (NWS) Advanced Hydrologic Prediction Service, which also presents the USGS data, at http://water.weather.gov/ahps/.

Flood profiles were computed for the stream reach by means of a one-dimensional step-backwater model. The model was calibrated by using the most current stage-discharge relation at the Flatrock River streamgage, high-water marks that were surveyed following the flood of June 7, 2008, and watersurface profiles from the current flood-insurance study for the City of Columbus. The hydraulic model was then used to compute 12 water-surface profiles for flood stages at 1-foot (ft) intervals referenced to the streamgage datum and ranging from $9 \mathrm{ft}$ or near bankfull to $20 \mathrm{ft}$, which exceeds the stages that correspond to both the estimated 0.2-percent annual exceedance probability flood (500-year recurrence interval flood) and the maximum recorded peak flow. The simulated water-surface profiles were then combined with a Geographic Information System digital elevation model (derived from Light Detection and Ranging (LiDAR) data having a $0.37 \mathrm{ft}$ vertical accuracy and $3.9 \mathrm{ft}$ horizontal resolution) to delineate the area flooded at each water level.

The availability of these maps on the USGS Federal Flood Inundation Mapper Web site, along with Internet information regarding current stage from the USGS streamgage, will provide emergency management personnel and residents with information that is critical for flood response activities, such as evacuations and road closures, as well as for postflood recovery efforts.

\section{Introduction}

The City of Columbus, in Bartholomew County, Indiana (Ind.), is a large urban community with an estimated population of 44,061 (U.S. Bureau of the Census, 2010). The Flatrock River, which flows southward near the western border of the city, has severely flooded numerous times in the past. Peak flows have been recorded since October 1967 at a U.S. Geological Survey (USGS) streamgage on the Flatrock River at Columbus (station number 03363900), about 2.6 miles (mi) upstream from its mouth. Prior to this time, Columbus experienced large floods during 1913 and 1963 (Federal Emergency Management Agency, 2011). Since October 1967, peak flows on the Flatrock River have approximated or exceeded the Federal Emergency Management Agency (FEMA) 10-percent annual exceedance probability flood (10-year recurrence interval flood) of 19,500 cubic feet per second $\left(\mathrm{ft}^{3} / \mathrm{s}\right)$ during 1968, 1990, 2004, and 2005. The highest of these peak flows, 22,400 $\mathrm{ft}^{3} / \mathrm{s}$ on January 7, 2005, was far exceeded by the period-of-record peak of $62,500 \mathrm{ft}^{3} / \mathrm{s}$ that occurred on June 7, 2008.

Prior to this study, emergency responders in Columbus and Bartholomew County relied on several information sources (all of which are available on the Internet) to make decisions on how to best alert the public and mitigate flood damages. One source is the FEMA flood insurance studies (FISs), which include the FIS for the City of Columbus dated January 5, 1996, (Federal Emergency Management Agency, 1996) and a preliminary version of a countywide FIS for Bartholomew County, which includes data from the 1996 City of Columbus FIS (Federal Emergency Management Agency, 2011). A second source of information is the USGS streamgage, Flatrock River at Columbus, from which current (U.S. Geological Survey, 2012a) and historical (that is, since 1968; U.S. Geological Survey, 2012b) water levels 
(stages) and discharges, including annual peak flows, can be obtained. A third source of flood-related information is the National Weather Service's (NWS) Advanced Hydrologic Prediction Service (AHPS), which also displays the USGS stage data from the Columbus streamgage (National Weather Service, 2012). The NWS forecasts flood hydrographs at many USGS streamgages but does not do so at the Flatrock River streamgage at Columbus.

Although the current stage at a USGS streamgage is particularly useful for residents in the immediate vicinity of a streamgage, it is of limited use to residents farther upstream or downstream because the water-surface elevation is not constant along the entire stream reach. Knowledge of a water level at a streamgage is difficult to translate into water levels-both their depth and aerial extent - at different locations along a stream. One way to address these informational gaps is to produce a library of flood-inundation maps that are referenced to the stages recorded at the USGS streamgage. By referring to the appropriate map, emergency responders can discern the severity of flooding (depth of water and aerial extent), identify roads that are or will soon be flooded, and make plans for notification or evacuation of residents in harm's way for some distance upstream and downstream from the streamgage. In addition, the capability to visualize the potential extent of flooding has been shown to motivate residents to take precautions and heed warnings that they previously might have disregarded. In 2011-12, the USGS, in cooperation with the Indiana Department of Transportation, conducted a project to produce a library of flood-inundation maps for the Flatrock River at Columbus, Ind.

\section{Purpose and Scope}

The purpose of this report is to describe the development of a series of estimated flood-inundation maps for the Flatrock River at Columbus, Ind., and to present the maps, which are also available on the USGS Flood Inundation Mapping Science Web site (U.S. Geological Survey, 2012c). The floodinundation maps cover a reach about $5 \mathrm{mi}$ long, from County Road 400N to the river mouth at the confluence with Driftwood River (fig. 1). The maps were produced for flood levels referenced to the stage recorded at the USGS streamgage on the Flatrock River at Columbus (03363900; table 1), which is at U.S. Route 31 about midway through the study reach. The maps cover a range in stage from 9 feet (ft), gage datum, or approximately bankfull, to $20 \mathrm{ft}$, gage datum, or greater than the water level associated with both the estimated 0.2-percent annual exceedance probability flood (500-year recurrence interval flood) and the maximum recorded peak flow.

Tasks specific to development of the flood maps for the Flatrock River at Columbus included (1) collection of topographic and bathymetric data for selected cross sections, and geometric data for structures and bridges along the study reach; (2) estimation of energy-loss factors (roughness coefficients) in the stream channel and flood plain, and steady-flow data; (3) computation of water-surface profiles by use of the U.S. Army Corps of Engineer's HEC-RAS computer program (U.S. Army Corps of Engineers, 2010); (4) production of estimated flood-inundation maps at various stream stages by use of the U.S. Army Corps of Engineer's HEC-GeoRAS computer program (U.S. Army Corps of Engineers, 2009) and

Table 1. U.S. Geological Survey streamgage information for Flatrock River at Columbus, Indiana.

[Station location is shown in figure 1. $\mathrm{ft}^{3} / \mathrm{s}$, cubic feet per second; NAVD 88 , North American Vertical Datum of 1988]

Station name

Station number

Drainage area (square miles)

Latitude

Longitude

Period of peak-flow record (water years')

Maximum recorded stage, in feet, gage datum (and elevation, in feet above NAVD 88) and date

Maximum discharge, in $\mathrm{ft}^{3} / \mathrm{s}$, and date
Flatrock River at Columbus, Indiana

03363900

534

$39^{\circ} 14^{\prime} 06^{\prime \prime}$

$85^{\circ} 55^{\prime} 36^{\prime \prime}$

$1968-2011$

19.94 (629.68) on June 7, 2008

62,500 on June 7, 2008

\footnotetext{
${ }^{1}$ Water year is the 12-month period from October 1 of one year through September 30 of the following year and is designated by the calendar year in which it ends.
} 


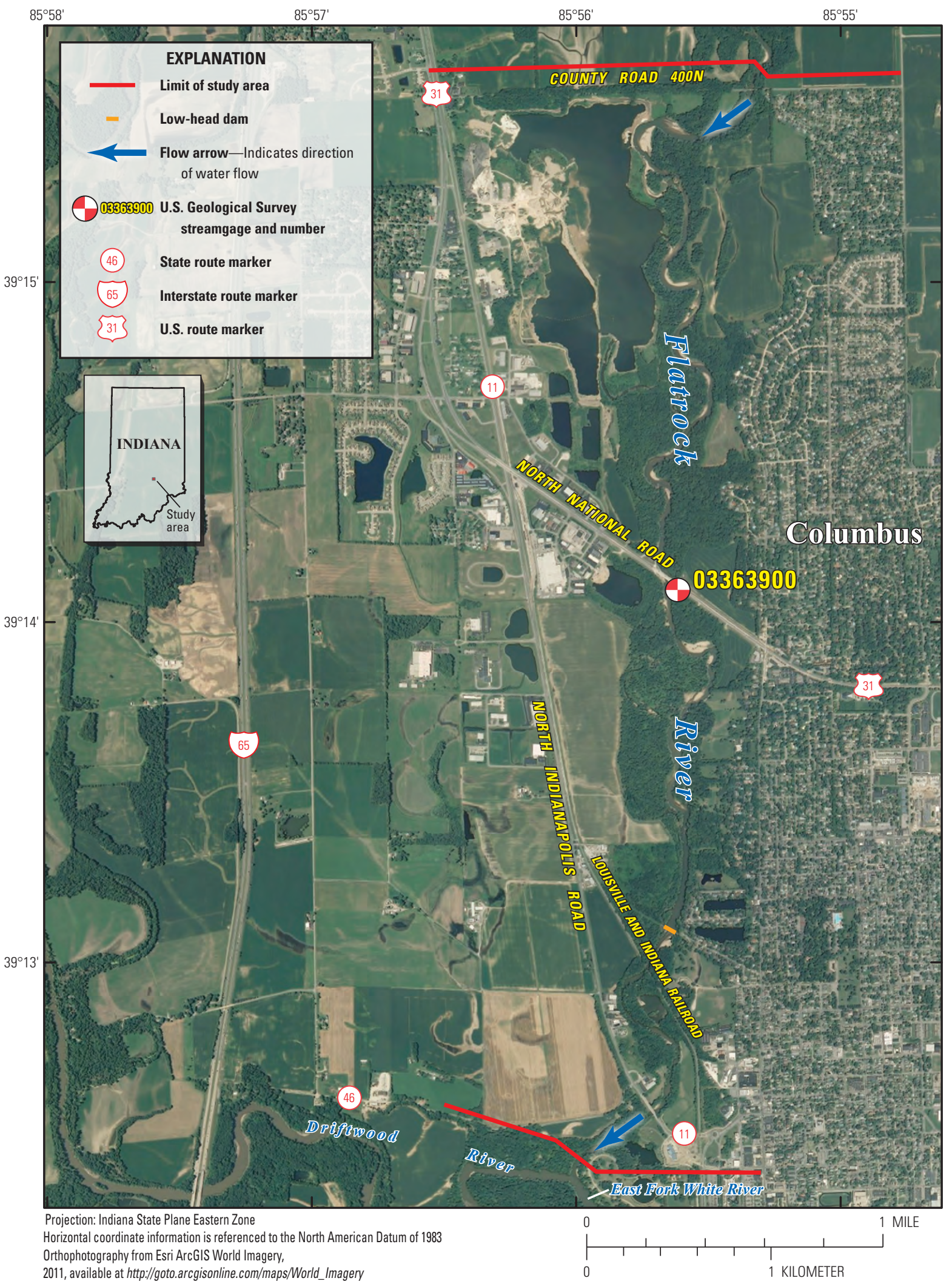

Figure 1. Location of study reach for the Flatrock River at Columbus, Indiana, and location of U.S. Geological Survey streamgage. 
a Geographic Information System (GIS); and (5) preparation of the maps, both as shapefile polygons that depict the areal extent of flood inundation and as depth grids that provide the depth of flood waters, for display on the USGS Federal Flood Inundation Mapper Web site (U.S. Geological Survey, 2012d). Techniques that varied substantially from previously documented methods because of local hydrologic conditions or available data are described in detail in this report.

\section{Study Area Description}

The Flatrock River, in the southeastern quarter of Indiana, rises in Henry County and flows southwesterly through Rush, Decatur, and Shelby Counties until in Bartholomew County it flows along the western side of the City of Columbus. At Columbus, the Flatrock River joins Driftwood River to form the East Fork White River. The drainage area of the Flatrock River Basin is 534 square miles at the USGS streamgage at Columbus, which is 2.6 mi upstream from the river mouth. There are no major tributaries to the Flatrock River that join the main stem as it flows through the study reach.

The study reach is approximately $5 \mathrm{mi}$ long and has an average top-of-bank channel width of 200-250 ft. The average channel slope is 0.0009 , whereas the high-watersurface slope is about 0.0006 . The main channel within the study reach is traversed by two major 4-lane highways, a 2-lane county road, a railroad, and a low-head dam. The basin terrain is generally flat, and the flood plain is dominated by agricultural uses; however, a large sand-and-gravel operation dominates the land on the upstream western part of the flood plain along the study reach. Large swaths of forested land cover the banks and flood plains adjacent to the river. Most of the densely developed areas of the City of Columbus, both residential and commercial uses, are on high ground to the east of the Flatrock River. Although most of these areas are safe from flooding, those residential areas closest to the river along the eastern edge of the flood plain are subject to inundation during major floods. Commercial and industrial establishments along the main roads that either cross the Flatrock River (U.S. Route 31 and State Route 11) or run parallel to the river along the western side of the flood plain (State Route 11) also are prone to flooding during moderate and major floods.

\section{Previous Studies}

The current FIS for the City of Columbus (Federal Emergency Management Agency, 1996) is a revision and update of the 1982 FIS (Federal Emergency Management Agency, 1982) and includes previously unincorporated areas of Bartholomew County that, by 1996, had been annexed to the city. Presently (March 2012), a preliminary version of a countywide FIS (Federal Emergency Management Agency, 2011) that will supersede the 1996 City of Columbus FIS is in the process of review and approval. The hydrologic and hydraulic analyses on which these studies were based were performed by the U.S. Army Corps of Engineers, Louisville District. The peak discharges and their frequencies of recurrence are the same in all three FISs, and, except for the change in datum from the National Geodetic Vertical Datum of 1929, which was used for the 1982 and 1996 FISs, to the North American Vertical Datum of 1988 (NAVD 88) that is used for the 2011 (preliminary) FIS, the water-surface elevations and resultant flood profiles are identical. The FISs present estimates of the peak discharges with $10,2,1$, and 0.2 percent annual exceedance probabilities and their associated water-surface elevations for the Flatrock River at Columbus streamgage at the U.S. Route 31 bridge. These flood frequencies are presented in table 2 .

Table 2. Peak discharges for selected annual exceedance probabilities for Flatrock River at Columbus, Indiana (streamgage number 03363900).

[ $\mathrm{ft}^{3} / \mathrm{s}$, cubic feet per second; ft, feet, FEMA, Federal Emergency Management Agency; NAVD 88, North American Vertical Datum of 1988; USGS, U.S. Geological Survey]

\begin{tabular}{|c|c|c|c|c|}
\hline $\begin{array}{c}\text { Annual } \\
\text { exceedance } \\
\text { probability } \\
\text { (percent) }\end{array}$ & $\begin{array}{c}\text { Discharge }^{1} \\
\quad\left(\mathrm{ft}^{3} / \mathrm{s}\right)\end{array}$ & $\begin{array}{c}\text { FEMA } \\
\text { water-surface } \\
\text { elevation }{ }^{1} \\
\text { (ft, NAVD 88) }\end{array}$ & $\begin{array}{c}\text { USGS } \\
\text { water-surface } \\
\text { elevation }{ }^{2} \\
\text { (ft, NAVD 88) }\end{array}$ & $\begin{array}{c}\text { Difference } \\
\text { in elevation } \\
\text { (ft) }\end{array}$ \\
\hline 10 & 19,500 & 625.3 & 625.7 & 0.4 \\
\hline 2 & 29,000 & 627.1 & 627.6 & .5 \\
\hline 1 & 32,500 & 627.7 & 628.0 & .3 \\
\hline 0.2 & 43,000 & 629.0 & 628.9 & -.1 \\
\hline
\end{tabular}

${ }^{1}$ Data from Federal Emergency Management Agency, 1982 and 1996.

${ }^{2}$ Values from most recent (January 2012) stage-discharge relation for Flatrock River at Columbus, Indiana. 


\section{Constructing Water-Surface Profiles}

The water-surface profiles used to produce the 12 floodinundation maps in this study were computed by using HECRAS, version 4.1.0 (U.S. Army Corps of Engineers, 2010). HEC-RAS is a one-dimensional step-backwater model for simulation of water-surface profiles with steady-state (gradually varied) or unsteady-state flow computation options.

\section{Hydrologic and Steady-State Flow Data}

The study reach includes one streamgage ( 03363900 ; fig. 1; table 1) that has been in operation since October 1967. Stage is measured every 15 minutes, transmitted hourly by a satellite radio in the gage, and made available on the Internet through the USGS National Water Information System (NWIS; U.S. Geological Survey, 2012a). Stage data from this gage are referenced to a local datum but can be converted to water-surface elevations referenced to the NAVD 88 by adding $609.74 \mathrm{ft}$. Continuous records of streamflow are computed from a stage-discharge relation that has been developed for the site and also are available through the USGS NWIS Web site. Longitudinal water-surface profiles from high-water marks along the main channel were documented following the flood of June 7, 2008 (Morlock and others, 2008), and were used for model calibration.

The HEC-RAS analysis for this study was done using the steady-state flow computation option. Steady-state flow data consisted of flow regime, boundary conditions (either known stage associated with a discharge measurement, critical depth, normal depth, or streamgage rating-curve value), and peak flows that produced water-surface elevations at the streamgage cross section that matched target water-surface elevations. These target elevations coincided with even 1-ft increments of stage, referenced to the local gage datum. Subcritical flow regime was assumed for the simulations. Initially, normal depth, based on an estimated average water-surface slope of 0.0008 from data contained in the FEMA FISs (Federal Emergency Management Agency, 1996; 2011), was used as the reach's downstream boundary condition. However, backwater at the confluence with Driftwood River at the downstream end of the study reach required that the boundary condition for high-stage flows (14- to 20 -ft flood profiles) be changed to a specific water-surface elevation for each profile to enable correct computation of water-surface elevations at the most downstream cross sections in the model. The peak flows used in the model simulations were taken from the current stagedischarge relation and corresponded with the target stages. No major tributaries join the Flatrock River within the 5-mi study reach; therefore, the gage-derived discharges were not adjusted for tributary inflows but were held constant throughout the study reach for a given profile.

\section{Topographic and Bathymetric Data}

All topographic data used in this study are referenced vertically to NAVD 88 and horizontally to the North American Datum of 1983. Cross-section elevation data were obtained from a digital elevation model (DEM) that was derived from Light Detection and Ranging (LiDAR) data that were collected as part of this project during April 2010 by AeroMetric, Inc., Sheboygan, Wisconsin. Postprocessing of these data was completed by AeroMetric, Inc., on July 14, 2010. The original LiDAR data have horizontal accuracy of $1.02 \mathrm{ft}$ (31 centimeters) with horizontal resolution of $3.9 \mathrm{ft}$ (1.2 meters) and vertical accuracy of $0.37 \mathrm{ft}$ at a 95 -percent confidence level for the "open terrain" land-cover category (root mean squared error of $0.19 \mathrm{ft}$ ( 5.8 centimeters)). Although a finer resolution of the DEM was possible given the accuracy of the LiDAR data, the final DEM was resampled to a grid-cell size of $10 \mathrm{ft}$ by $10 \mathrm{ft}$ to decrease the GIS processing time. By using HEC-GeoRAS, a set of procedures, tools, and utilities for processing geospatial data in ArcGIS, elevation data were extracted from the DEM for 53 cross sections and subsequently were input to the HECRAS model. Because LiDAR data cannot provide ground elevations below a stream's water surface, channel cross sections were surveyed by USGS field crews during 2011. Cross-sectional depths were measured by using hydroacoustic instrumentation, whereas a differential global positioning system (DGPS) with real-time kinematic (RTK) technology was used to derive horizontal locations and the elevation of the water surface at each surveyed cross section. Elevations determined by RTK DGPS at three benchmark locations were within $0.08-0.21 \mathrm{ft}$ of the known elevations, an error range that falls within the accuracy of the LiDAR data. Where possible, DEM-generated cross sections were made to coincide with the locations of the within-channel field-surveyed cross sections. In these cases, within-channel data were directly merged with the DEM data. For all other cross sections, the within-channel data were estimated by interpolation from the closest field-surveyed cross section. This interpolation was accomplished by (1) assuming that the channel geometry at an unsurveyed cross section was comparable to that of the nearest surveyed cross section; (2) estimating the thalweg elevation at each unsurveyed cross section based on the channel slope, which was assumed to be constant between adjacent surveyed cross sections; and (3) adjusting the within-channel elevations of the surveyed cross section by the difference between the thalweg elevations at the surveyed and unsurveyed cross sections and applying these adjusted elevations to the unsurveyed cross section.

Five structures, consisting of three road crossings (County Road 400N, U.S. Route 31, and State Route 11), a railroad bridge, and a low-head dam, have the potential to affect water-surface elevations during floods along the stream. Bridge geometry data for the County Road $400 \mathrm{~N}$ bridge at 
the upstream end of the study reach were obtained from 1998 bridge plans provided by the Bartholomew County Highway Department (D. Hollander, County Engineer, Bartholomew County Highway Department, written commun., 2012). Data for the Route 31 (National Road) bridge at the USGS gage were obtained from a 2008 indirect measurement of discharge made by the USGS. Data for the Route 11 (Indianapolis Road) bridge and the low-head dam were obtained from USGS field surveys. The Louisville \& Indiana Railroad Company owns two bridges that carry the railroad over an overflow channel on the left (eastern) flood plain and the main channel. Geometric data for the overflow bridge were obtained partly by a USGS field survey; additional data for the overflow bridge and that for the main bridge were obtained from a HEC-2 model (U.S. Army Corps of Engineers, 1972) that was developed and used for the 1982 FIS (Federal Emergency Management Agency, 1982).

\section{Energy-Loss Factors}

Initial (precalibration) Manning's roughness coefficients ( $n$ values) for energy-loss (friction-loss) calculations were estimated by comparison of field photographs with photographs of channels for which $n$ values have been computed and published in references, such as Barnes (1967), Coon (1998), and Hicks and Mason (1991). An $n$ value of 0.045 was selected for the wide, low-gradient main channel with sandy bed and treelined banks. The flood plains have mixed land uses but are dominated by agriculture and a large sand-and-gravel operation, which covers the right (west) flood plain in the upper half of the study reach. Forested areas cover wide swaths of land on both banks and flood plains adjacent to the river. Densely populated residential areas of Columbus are east of the Flatrock River, but these areas are mostly on elevated ground above the left flood plain. A composite $n$ value (0.070) that was presumed to represent the diverse energy-loss factors of these land types was deemed appropriate to use for the initial estimate of the flood plain $n$ value.

The initial $n$ values were adjusted as part of the calibration process. The HEC-RAS model was calibrated to (1) the stage-discharge relation at the USGS gage, (2) water-surface profiles included in the most recent FIS (Federal Emergency Management Agency, 1996), and (3) high-water marks that were surveyed following the June 7, 2008, flood in the downstream half of the study reach. These marks, which corresponded to a stage of $19.94 \mathrm{ft}$ at the USGS gage, were applicable to the greatest (20-foot stage) flow that was simulated as part of this project. Calibration of the model followed a threestep process. (1) Roughness-coefficient adjustment factors that were varied by flow and applied to the initially selected $n$ values were adjusted until the water-surface elevations for the simulated within-bank flows matched those for the observed flows at the USGS gage. The actual $n$ values were computed by multiplying the initial $n$ value by each of the roughnesscoefficient adjustment factors. These computed values were then input to the "vertical variation in $n$ value" table for each cross section in the study reach. (2) While keeping the mainchannel $n$ values constant, the roughness-coefficient factors were adjusted once again until the water-surface elevations for simulated overbank flows matched those for observed flows at the USGS gage. The actual $n$ values were again computed, this time for the overbank areas, and these values were input to the "vertical variation in $n$ value" table for each cross section. (3) Minor adjustments to the overbank $n$ values were made to improve the final match between observed and simulated water-surface elevations at the USGS gage. Final mainchannel $n$ values ranged from 0.044 to 0.058 , and those for the overbank areas ranged from 0.100 to 0.153 .

The simulated water-surface elevations at the upstream end of the study reach, near County Road 400N, were lower than those published in the current FIS (Federal Emergency Management Agency, 1996). A noticeable decrease in the simulated water-surface slope in the upper quarter of the study reach was evident. The HEC-2 model that was used to compute water-surface profiles for the 1982 FIS and on which the current effective flood-insurance maps are based did not include any cross sections in this subreach of the study reach. Nevertheless, to improve agreement between the simulated and FIS water-surface elevations near County Road 400N, roughness-coefficient adjustment factors were increased to raise the water-surface slope. The increases in the roughness coefficient were attributed to the presence of sharp meander bends in the main channel, the heavy vegetation across meander bends that would impede out-of-bank flows, and the diversion of flows across a low bank into and through excavation ponds of a sand-and-gravel operation on the right (west) flood plain in this part of the study reach. The resultant $n$ values in the upstream quarter of the study reach ranged from 0.064 to 0.116 for the main channel and from 0.130 to 0.276 in the overbank areas.

\section{Model Calibration and Performance}

As described in the previous section, the HEC-RAS model was calibrated to (1) the most current stage-discharge relation at the Flatrock River streamgage, (2) high-water marks that were surveyed following the June 7, 2008 flood, and (3) FEMA FIS water-surface elevations. Collectively, the calibration results demonstrated that the HEC-RAS model is capable of simulating accurate water levels over a wide range of flows in the study reach. Roughness coefficients and coefficients to account for energy losses due to expansion and contraction of flow at bridge constrictions were adjusted to minimize the differences between simulated and observed (target) water-surface elevations. The maximum difference between observed and simulated water-surface elevations at 
the USGS gaging station 03363900 (at the downstream side of the U.S. Route 31 bridge) for the 12 simulated flows was $0.03 \mathrm{ft}$ (table 3).

High-water marks that were surveyed following the flood of June 7, 2008, were used as approximate target elevations for the water-surface profile from the mouth of Flatrock River to the U.S. Route 31 bridge (fig. 2). The marks represent water levels for a flow of $62,500 \mathrm{ft}^{3} / \mathrm{s}$ (computed by indirect methods by Morlock and others, 2008) at a streamgage stage of $19.94 \mathrm{ft}$ and were compared with the water-surface profile generated by a flow of $61,200 \mathrm{ft}^{3} / \mathrm{s}$, which was taken from the stagedischarge relation for a stage of $20.00 \mathrm{ft}$. Large discrepancies between surveyed and simulated elevations (greater than $0.5 \mathrm{ft}$ ) were found for high-water marks that were rated "poor" by USGS personnel at the time that the marks were surveyed. Marks that were rated "good" to "fair" were within $0.4 \mathrm{ft}$ of the simulated water-surface profile.

Water-surface profiles for 10-, 2-, 1-, and 0.2-percent annual peak-flow exceedance probabilities were computed and presented in the 1996 FIS (Federal Emergency Management Agency, 1996). The profile for the 1-percent probability flood (100-year recurrence interval flood) of $32,500 \mathrm{ft}^{3} / \mathrm{s}$ at a streamgage stage of $18.27 \mathrm{ft}$ was compared with the simulated water-surface profiles that were generated by the hydraulic model for the streamgage flows of 30,000 and $40,000 \mathrm{ft}^{3} / \mathrm{s}$ at stages of 18 and $19 \mathrm{ft}$, respectively (fig. 3). The expectation was that the FIS profile would fall near or between the two simulated profiles. This expectation was realized for most of the reach; however, one anomalously high FIS elevation, $625.5 \mathrm{ft}$, at river station $5,634 \mathrm{ft}$, was noted. This elevation is actually higher than the surveyed high-water mark (625.0 ft) for the June 2008 flow of $62,500 \mathrm{ft}^{3} / \mathrm{s}$, as shown in figure 2 . Therefore, this discrepancy in the compared profiles was disregarded. Similarly, the flood extent of the FEMA 1-percent probability flood was compared with the simulated inundated areas for flows that bracket this flood, that is, the flows corresponding to the streamgage stages of 18 and $19 \mathrm{ft}$ (fig. 4). The FEMA delineation is an interim version of a digital Flood Insurance Rate Map (Indiana Department of Natural Resources, 2004) and is presented herein for comparison purposes only.

\section{Development of Water-Surface Profiles}

Profiles were developed for a total of 12 stages at $1-\mathrm{ft}$ intervals between $9 \mathrm{ft}$ and $20 \mathrm{ft}$ as referenced to the local datum of the Flatrock River at Columbus streamgage. These stages correspond to elevations of $618.74 \mathrm{ft}$ and $629.74 \mathrm{ft}$, NAVD 88, respectively. Discharges corresponding to the various stages were obtained from the most current stagedischarge relation (rating 23, effective February 5, 2010) at the Flatrock River gage. No major tributaries join the Flatrock River within the 5-mi study reach; therefore, the discharges (as listed in table 3) were held constant throughout the study reach for a given profile.

Table 3. Calibration of model to target water-surface elevations at U.S. Geological Survey streamgage on Flatrock River at Columbus, Indiana (station number 03363900).

[NAVD 88, North American Vertical Datum of 1988; $\mathrm{ft}^{3} / \mathrm{s}$, cubic feet per second]

\begin{tabular}{ccccc}
\hline $\begin{array}{c}\text { Water-surface } \\
\text { profile }^{1}\end{array}$ & $\begin{array}{c}\text { Discharge, } \\
\text { corresponding to target } \\
\text { water-surface elevation } \\
\text { (ft } \mathbf{3}^{\mathbf{s} \text { ) }}\end{array}$ & $\begin{array}{c}\text { Target } \\
\text { water-surface } \\
\text { elevation } \\
\text { (feet, NAVD 88) }\end{array}$ & $\begin{array}{c}\text { Modeled } \\
\text { water-surface } \\
\text { elevation } \\
\text { (feet, NAVD 88) }\end{array}$ & $\begin{array}{c}\text { Difference } \\
\text { in elevation } \\
\text { (feet) }\end{array}$ \\
\hline 9 & 3,400 & 618.74 & 618.73 & -0.01 \\
10 & 4,440 & 619.74 & 619.73 & -0.01 \\
11 & 5,700 & 620.74 & 620.71 & -0.03 \\
12 & 7,310 & 621.74 & 621.72 & -0.02 \\
13 & 9,320 & 622.74 & 622.72 & -0.02 \\
14 & 12,200 & 623.74 & 623.74 & 0.00 \\
15 & 15,700 & 624.74 & 624.74 & 0.00 \\
16 & 19,800 & 625.74 & 625.74 & 0.00 \\
17 & 24,500 & 626.74 & 626.73 & -0.01 \\
18 & 30,000 & 627.74 & 627.74 & 0.00 \\
19 & 40,000 & 628.74 & 628.76 & 0.02 \\
20 & 61,200 & 629.74 & 629.76 & 0.02 \\
\hline
\end{tabular}

${ }^{1}$ Water-surface profiles are one-foot increments of stage, referenced to the gage datum of the U.S. Geological Survey streamgage. 

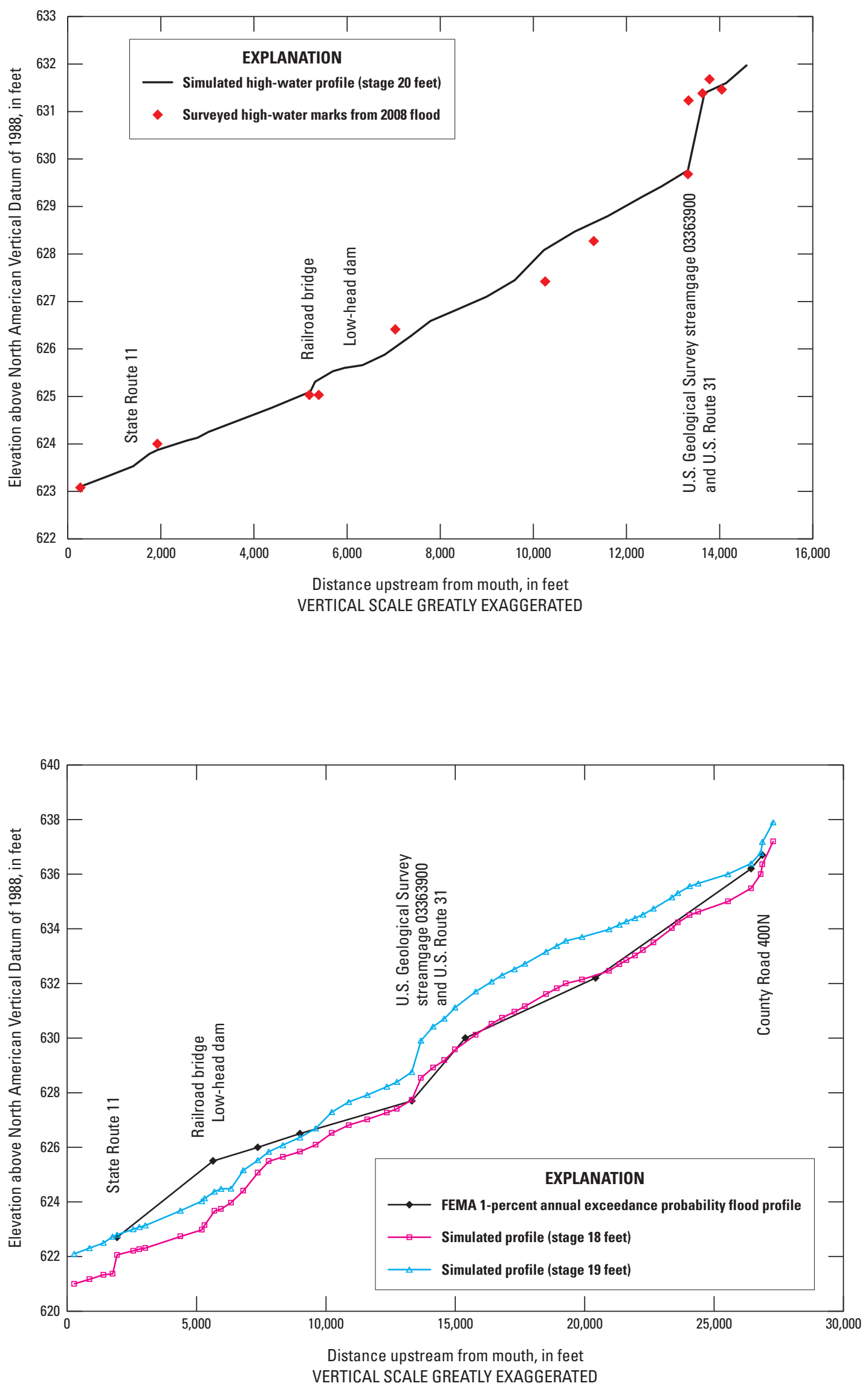

Figure 2. Simulated water-surface profile at a streamgage stage of 20.00 feet and highwater marks surveyed following the flood of June 7,2008 , at a stage of 19.94 feet, Flatrock River at Columbus, Indiana.
Figure 3. High watersurface profiles of the FEMA 1-percent annual exceedance probability flood and simulated floods corresponding to streamgage stages of 18 and 19 feet for Flatrock River at Columbus, Indiana. 


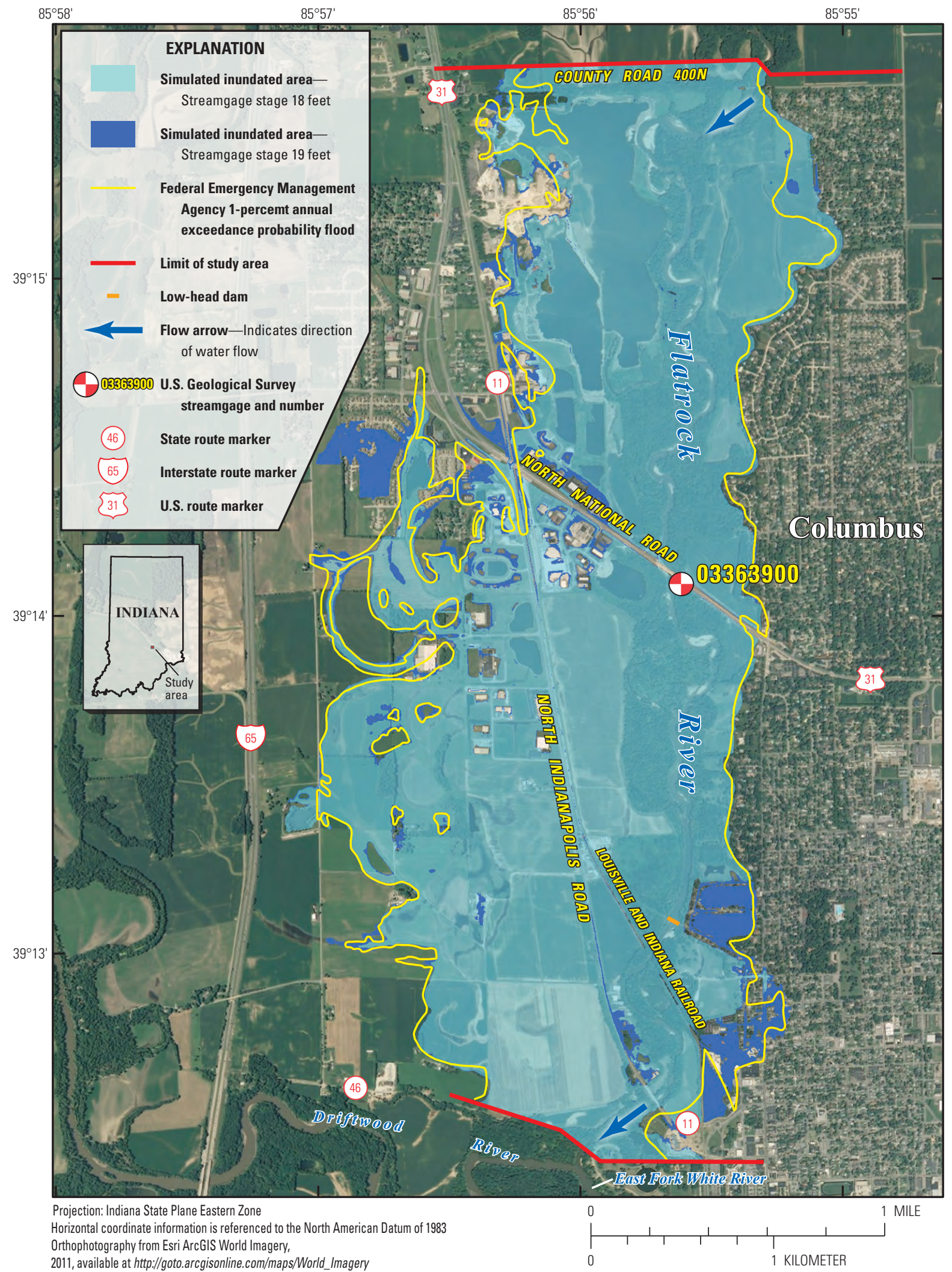

Figure 4. Flood extents of the FEMA 1-percent annual exceedance probability flood and simulated floods corresponding to streamgage stages of 18 and 19 feet for Flatrock River at Columbus, Indiana. 


\section{Development of Flood-Inundation Maps}

Flood-inundation maps were created in a Geographic Information System (GIS) for the 12 water-surface profiles by combining the profiles and digital elevation model (DEM) data. The DEM data were derived from the same LiDAR data described previously in the section "Topographic and Bathymetric Data." Estimated flood-inundation boundaries for each simulated profile were developed with HEC-GeoRAS software (U.S. Army Corps of Engineers, 2009). As with the resampled LiDAR data (10 ft by $10 \mathrm{ft}$ grid-cell size), from which the flood maps were derived, the resulting flood maps have an estimated vertical accuracy of $2 \mathrm{ft}$ (that is, plus or minus $1 \mathrm{ft}$ ). Shapefile polygons and depth grids of the inundated areas for each profile were modified, as required, in the ArcMap application of ArcGIS (Esri, 2012) to ensure a hydraulically reasonable transition of the flood boundaries between modeled cross sections. Any inundated areas that were detached from the main channel and, therefore, erroneously delineated as parts of the flood extent were removed from the mapped inundated areas. Bridge surfaces are shown as non-inundated up to the lowest flood stage that either intersects the lowest structural chord of the bridge or completely inundates one or both approaches to the bridge. In these latter circumstances, the bridge surface is depicted as being inundated. Estimates of water depth can be obtained from the depth-grid data that are included with the presentation of the flood maps on the interactive online map-library Web site described in the following section, "Flood-Inundation Maps on the Internet." The mapped areas of inundation are overlaid on high-resolution, georeferenced aerial photographs of the study area. The most up-todate orthoimagery available was downloaded from an ArcGIS online world imagery base map (Esri, 2011) for this purpose.

\section{Flood-Inundation Maps on the Internet}

The flood-inundation maps and current study documentation are available online at the U.S. Geological Survey Publications Warehouse (http://pubs.usgs.gov/sim/2012/3241). Also, a Flood Inundation Mapping Science Web site (U.S. Geological Survey, 2012c) has been established to provide a portal at http://water.usgs.gov/osw/flood_inundation/to make USGS flood-inundation study information available to the public. That Web portal has a link to an interactive flood mapper Web site (U.S. Geological Survey, 2012d) at http://wim.usgs.gov/ FIMI/FloodInundationMapper.html that presents map libraries that provide detailed information on flood extents and depths for selected sites, including Flatrock River at Columbus. Included on this latter Web site is a link to the USGS National Water Information System (http://waterdata.usgs.gov/in/nwis/ $u v$ ? site_no=03363900), which presents graphs of the current stage and streamflow at the USGS streamgage 03363900 to which the inundation maps are referenced. A link also is provided to the NWS Advanced Hydrologic Prediction Service
(AHPS) site (http:/water.weather.gov/ahps/); however, because the NWS does not forecast stage at this site, the data presented on the USGS and NWS Web sites are identical. The estimated flood-inundation maps are displayed in sufficient detail to note the extent of flooding with respect to individual structures so that preparations for flooding and decisions for emergency response can be performed efficiently. Roadways and bridges were closely reviewed and are shown as shaded (inundated and likely impassable) or not shaded (dry and passable) to facilitate emergency planning and use. However, buildings which are shaded do not reflect inundation but denote that bare earth surfaces in the vicinity of the buildings are inundated. When the water depth (as indicated in the Web Mapping Application by holding the cursor over an inundated area) in the vicinity of the building of interest exceeds that building's height, the structure can be considered fully submerged.

\section{Disclaimer for Flood-Inundation Maps}

Inundated areas shown on the flood maps should not be used for navigation, regulatory, permitting, or other legal purposes. The USGS provides these maps "as-is" for a quick reference, emergency planning tool but assumes no legal liability or responsibility resulting from the use of this information.

\section{Uncertainties and Limitations Regarding Use of Flood-Inundation Maps}

Although the flood-inundation maps represent the boundaries of inundated areas with a distinct line, some uncertainty is associated with these maps. The flood boundaries shown were estimated on the basis of water stages at the USGS streamgage on the Flatrock River at Columbus (03363900). Water-surface elevations along the stream reaches were estimated by steady-state hydraulic modeling, assuming unobstructed flow, and using streamflows and hydrologic conditions anticipated at the USGS streamgage. The hydraulic model reflects the land-cover characteristics and any bridge, dam, levee, or other hydraulic structures existing as of March 2012. Unique meteorological factors (timing and distribution of precipitation) may cause actual streamflows along the modeled reach to vary from those assumed during a flood, which may lead to deviations in the water-surface elevations and inundation boundaries shown. Additional areas may be flooded due to unanticipated conditions, such as changes in the streambed elevation or roughness, backwater into major tributaries along a main-stem river, or backwater from localized debris or ice jams. The accuracy of the floodwater extent portrayed on these maps will vary with the accuracy of the digital elevation model used to simulate the land surface. Additional uncertainties and limitations pertinent to this study may be described elsewhere in this report.

If this series of flood-inundation maps will be used in conjunction with National Weather Service (NWS) river 
forecasts, the user should be aware of additional uncertainties that may be inherent or factored into NWS forecast procedures. The NWS uses forecast models to estimate the quantity and timing of water flowing through selected stream reaches in the United States. These forecast models (1) estimate the amount of runoff generated by precipitation and snowmelt, (2) simulate the movement of floodwater as it proceeds downstream, and (3) predict the flow and stage (water-surface elevation) for the stream at a given location (AHPS forecast point) throughout the forecast period (every 6 hours and 3 to 5 days out in many locations). For more information on AHPS forecasts, please see http://water.weather.gov/ahps/pcpn_and_ river forecasting. $p d f$.

\section{Acknowledgments}

The author wishes to thank the Indiana Department of Transportation, which has cooperated in the funding for the operation and maintenance of the gage used for this study, and personnel from the City of Columbus-Bartholomew County Planning Department, who reviewed the flood-inundation maps. Special thanks are given to the National Weather Service for their continued support of the U.S. Geological Survey flood-inundation mapping initiative.

\section{Summary}

A series of 12 digital flood-inundation maps were developed in cooperation with the Indiana Department of Transportation for the Flatrock River at Columbus. The maps cover a reach about $5 \mathrm{mi}$ long from the river mouth at its confluence with Driftwood River upstream to County Road $400 \mathrm{~N}$. The maps were developed by using the U.S. Army Corps of Engineers' HEC-RAS and HEC-GeoRAS programs to compute water-surface profiles and to delineate estimated flood-inundation areas and depths of flooding. The HEC-RAS hydraulic model was calibrated by using the most current stage-discharge relation at the Flatrock River streamgage, high-water marks that were surveyed following the flood of June 7, 2008, and water-surface profiles from the current flood-insurance study for the City of Columbus. The model was used to compute 12 water-surface profiles for flood stages at 1-ft intervals referenced to the streamgage datum and ranging from $9 \mathrm{ft}$ or near bankfull to $20 \mathrm{ft}$, which exceeds the stages that correspond to both the estimated 0.2-percent annual exceedance probability flood (500-year recurrence interval flood) and the maximum recorded peak flow. The simulated water-surface profiles were then combined with a Geographic Information System (GIS) digital elevation model (derived from Light Detection and Ranging (LiDAR) data) to delineate estimated flood-inundation areas as shapefile polygons and depth grids for each profile. These flood-inundation polygons were overlaid on high-resolution, georeferenced aerial photographs of the study area.

Interactive use of the maps on a USGS flood-inundation mapping Web portal can give users a general indication of depth of water at any point by using the mouse cursor to click within the shaded areas. These maps, in conjunction with the real-time stage data from the USGS streamgage Flatrock River at Columbus (station number 03363900), will help to guide the general public in taking individual safety precautions and will provide emergency management personnel with a tool to efficiently manage emergency flood operations and post-flood recovery efforts.

\section{References Cited}

Barnes, H.H., Jr., 1967, Roughness characteristics of natural channels: U.S. Geological Survey Water-Supply Paper 1849, 213 p.

Coon, W.F., 1998, Estimation of roughness coefficients for natural stream channels with vegetated banks: U.S. Geological Survey Water-Supply Paper 2441, 133 p. (Also available at http://pubs.usgs.gov/wsp/2441/report.pdf.)

Esri, 2011, ArcGIS World Imagery, accessed September, 2011, at http://www.arcgis.com/home/item.html? id=10df2279f968 $4 e 4 a 9 f 6 a 7 f 08 f e b a c 2 a 9$.

Esri, 2012, ArcGIS, accessed August 7, 2012, at http://www. esri.com/software/arcgis/.

Federal Emergency Management Agency, 1982, Flood Insurance Study, City of Columbus, Indiana, Bartholomew County: Washington D.C., 23 p., 8 pl.

Federal Emergency Management Agency, 1996, Flood Insurance Study, City of Columbus, Bartholomew County, Indiana: Washington D.C., 23 p., 19 pl.

Federal Emergency Management Agency, 2011, Preliminary Flood Insurance Study, Bartholomew County, Indiana, and incorporated areas: Washington D.C., 32 p., 34 pl., and interim digital flood-insurance rate maps (DFIRMS, dated 2004), accessed April 2, 2012, at http://www.in.gov/dnr/ water $/ 7246 . \mathrm{htm}$.

Hicks, D.M., and Mason, P.D., 1991, Roughness characteristics of New Zealand rivers: Wellington, New Zealand, Water Resources Survey, DSIR Marine and Freshwater, 329 p.

Indiana Department of Natural Resources, 2004, Digital flood insurance rate map database, Bartholomew County, Indiana, USA, accessed April 2, 2012, at http://www.in.gov/dnr/ water $/ 7246 . \mathrm{htm}$. 
Morlock, S.E., Menke, C.D., Arvin, D.V., and Kim, M.H., 2008, Flood of June 7-9, 2008, in central and southern Indiana: U.S. Geological Survey Open-File Report 2008-1322, 15 p., 3 app.

National Weather Service, 2012, Advanced Hydrologic Prediction Service, accessed May 9, 2012, at http://water.weather. gov/ahps2/hydrograph.php? wfo $=$ ind\&gage $=$ flci3 .

U.S. Army Corps of Engineers, 1972, Computer program, HEC2, water-surface profiles: U.S. Army Corps of Engineers, Hydrologic Engineering Center, 132 p.

U.S. Army Corps of Engineers, 2009, HEC-GeoRAS, GIS tools for support of HEC-RAS using ArcGIS, User's Manual, version 4.2: U.S. Army Corps of Engineers, Hydrologic Engineering Center [variously paged].

U.S. Army Corps of Engineers, 2010, HEC-RAS River Analysis System, Hydraulic Reference Manual, version 4.1: U.S. Army Corps of Engineers, Hydrologic Engineering Center [variously paged].

U.S. Bureau of the Census, 2010, American FactFinder, accessed May 8, 2012, at http://factfinder2.census.gov.

U.S. Geological Survey, 2012a, USGS 03363900 Flatrock River at Columbus, IN: U.S. Geological Survey, accessed May 9, 2012, at http://waterdata.usgs.gov/in/nwis/uv?site_ $n o=03363900$.

U.S. Geological Survey, 2012b, USGS Surface-water data for the Nation: U.S. Geological Survey, accessed May 9, 2012, at http://waterdata.usgs.gov/nwis/sw.

U.S. Geological Survey, 2012c, USGS Flood Inundation Mapping Science: U.S. Geological Survey, accessed May 9, 2012, at http://water.usgs.gov/osw/flood_inundation/ toolbox/.

U.S. Geological Survey, 2012d, Federal flood inundation mapper: U.S. Geological Survey, accessed May 9, 2012, at http://wim.usgs.gov/FIMI/FloodInundationMapper.html. 
For additional information contact:

Director, Indiana Water Science Center

5957 Lakeside Blvd.

Indianapolis, IN 46278

http://in.water.usgs.gov/

Publishing support provided by: West Trenton Publishing Service Center 
